\title{
A recepção de Nietzsche na Primeira Escola de Formação Pastoral da Igreja Evangélica de Confissão Luterana no Brasil
}

\author{
Adilson Felicio Feiler*
}

Resumo: Como rebento de uma família de tradição luterana, Nietzsche não poderia estar ausente do rico material produzido nos quase cem anos da presença da Escola Superior de Teologia (EST). Mesmo que o acervo bibliográfico da dita Escola esteja eminentemente voltado ao atendimento do curso de teologia, há um acervo filosófico digno de nota. Entre os diversos volumes que preenchem as dezenas de estantes da filosofia, se encontram textos escritos por Nietzsche, bem como livros escritos sobre este autor. A maioria destes escritos em língua alemã na Alemanha, mas também inúmeros escritos em alemão, porém no Brasil. Neste artigo pretendemos analisar estes últimos escritos, de maneira a realizar uma leitura de como foi a recepção de Nietzsche na primeira escola de formação de pastores do Brasil.

Palavras-chave: Nietzsche, Lutero, protestantismo, recepção, Brasil.

\footnotetext{
* Professor do Programa de Pós-Graduação em Filosofia da Universidade do Vale do Rio dos Sinos, São Leopoldo, RS, Brasil.

ORCID https://orcid.org/0000-0001-7352-927X

Correio eletrônico: afeiler@unisinos.br
} 
Feiler, A. F.

\section{Introdução}

A Escola Superior de Teologia, localizada no Bairro Morro do Espelho na cidade de São Leopoldo, no Estado do Rio Grande do Sul, é um centro de excelência quanto ao ensino de teologia. Ela marca uma fase importante da investigação teológica: referente às buscas do Jesus histórico, motivada pelas últimas descobertas arqueológicas realizadas. A demanda principal em ter um Centro de formação Teológico no Brasil diz respeito à formação de novos Pastores para o exercício do ministério entre as comunidades Luteranas, compostas por imigrantes alemães vindos ao Brasil desde 1824, que, aos poucos, foi se espalhando por todo o país. Os inícios da Escola Superior de Teologia remontam à criação, em 1921, do curso de formação humanística para o Ensino Médio, o pré-instituto teológico. Este, em 1940 passa a curso teológico propedêutico, para, em 1946, ser oficialmente a Faculdade de Teologia. No princípio da existência da Escola Superior da Teologia, entre as décadas de 30 até 60, os professores, bem como o acervo bibliográfico que compunha a biblioteca, provinham da Alemanha. Daí a razão de $80 \%$ do acervo bibliográfico estar em língua alemã, além do fato de ser o alemão o idioma oficial da Igreja Luterana.

Entre os livros e revistas que compõem a biblioteca a maior parte é de teologia, para o atendimento do curso de teologia. No entanto, a biblioteca também conta com um acervo considerável de livros de outras áreas como filosofia, história e música sacra. Quanto a esta última, na década de 50 foi inaugurada na mesma Escola Superior de Teologia um curso de música sacra, para a formação complementar em música dos pastores, já que a música foi desde a fundação da Igreja um instrumento fundamental no ministério. $\mathrm{O}$ mesmo, no entanto, não se pode dizer da filosofia. $\mathrm{O}$ que dela se teve durante a existência do curso de teologia se resumiu a uma cadeira de um semestre em todos os quatro anos de duração do curso. 
A recepção de Nietzsche na Primeira Escola de Formação Pastoral...

Mesmo que a filosofia não fosse ensinada exaustivamente com todas as suas sub-áreas e tratados, é digno de nota que em diversas revistas é mencionado o pensamento de dois filósofos: Tomás de Aquino e Kant. O primeiro é mencionado como o mentor teológico católico e o segundo como o inspirador da teologia luterana. O pietismo que se depreende da filosofia de Kant é uma das marcas fundamentais do modelo de teologia luterana. A metafísica que supera a natureza, a parte indestrutível do espírito que conduz à fé. Outra referência importante que tem preenchido inúmeras páginas de artigos em revistas da biblioteca é a Goethe. A razão que se atribui a isso é devida à beleza de sua escrita. Pois a língua vernácula alemã que já havia sido refundada por Lutero com a tradução da Bíblia Sagrada, no período da Reforma Protestante, uma vez mais passa por uma segunda refundação, mediante a poesia de Goethe.

Diante destas considerações percebemos que a filosofia cumpre um papel muito importante à teologia, não apenas pelo conteúdo propriamente dito, mas também pela forma, ao que diz respeito a estilística. Ora, em falar de estilística em filosofia não poderia faltar o nome Nietzsche. Deste filósofo alemão existem na biblioteca inúmeras obras, bem como inúmeras referências a ele em livros e artigos. Nietzsche é fundamentalmente recordado por sua beleza estilística, razão pela qual é responsável pela terceira refundação pela qual passa a língua alemã. Oriundo de uma família de pastores, o Filósofo alemão tem como temas reflexivos de seu horizonte filosófico, o Cristianismo. De maneira específica, ao que toca a Confissão Cristã Luterana, o filósofo critica o seu pietismo e moralismo fundado no kantismo. No entanto, no que tange a sua recepção na Escola Superior de Teologia, o nome Nietzsche é muito mais fortemente associado às questões literárias. O elemento estilístico se depreende como um traço fundamental, pois dele, mais uma vez, se pode realçar o valor da língua alemã, tão fortemente ressaltado por Lutero. Além do elemento estilístico, vale recordar o grande

Cad. Nietzsche, Guarulhos/Porto Seguro, v.40, n.3, p. 241-267, setembro/dezembro, 2019. | 243 
Feiler, A. F.

valor que entre os luteranos se dá ao aspecto aristocrata. Nietzsche acentua a aristocracia pela importância que atribui a cada um ser mestre de si mesmo distanciando-se do rebanho. Na teologia luterana o aspecto de individualidade se depreende do caminho que cada fiel deve realizar orientado unicamente pela fé. E, finalmente, ainda um terceiro traço que se depreende da recepção do pensamento de Nietzsche na Escola Superior de Teologia está ligado a uma leitura que dele se fez, leitura hoje, em grande parte, desconstruída: o nazismo que seus textos, supostamente, inspiraram. Pois houve uma relação bastante estreita entre a Igreja luterana e o nazismo. Esta relação se deve a concessão mútua entre Igreja e Estado defendida por Lutero. Precisamente, em sua doutrina dos dois reinos, Lutero exalta a ordenação mútua de ambos por Deus.

Assim, é em torno a estes três elementos: a estilística, a singularidade individual e o nazismo que a Escola Superior de Teologia irá recepcionar o pensamento de Nietzsche. No decorrer destas páginas iremos apresentar excertos de textos localizados na biblioteca da Escola Superior de Teologia que ilustram estes diferentes aspectos aos quais o pensamento de Nietzsche é tributário. No primeiro capítulo apresentamos referências que apontam para a importância que Nietzsche exerce como estilista da língua, o intitulamos "A estilística como leere Formalität (formalidade vazia). Nietzsche Philosoph und Dichter (filósofo e poeta)". Seguimos nossa investigação, no segundo capítulo, aprofundando o aspecto da singularidade de Nietzsche, o denominamos: "Nietzsche e o seu Selber Aner (ele mesmo)". Finalmente, no terceiro capítulo, atentamos para os elementos nazistas que foram extraídos da escrita de Nietzsche, intitulamos "O Barteifuihrer (líder do partido) de Nietzsche." 


\section{A estilística como leere Formalität (formalidade vazia). Nietzsche Philosoph und Dichter (filósofo e poeta)}

A influência mais forte que o pensamento de Nietzsche tem exercido em seus leitores tem sido, sem sombra de dúvidas, sobre a sua estilística. $O$ estilo de Nietzsche revoluciona, descontrói, enfeitiça. Em diversos círculos literários seus escritos têm sido recepcionados com entusiasmo, como o foi na Dinamarca pelo crítico literário Georg Brandes. Recepção esta reconhecida e agradecida pelo próprio Nietzsche. No Brasil também não foi diferente, quando diversas referências aos escritos de Nietzsche foram sendo incorporados na literatura, como é o caso do germanófilo Tobias Barreto no Recife em 1870. Dele o Pastor Hermann Dohms fala: “Tobias Barreto tem descoberto em 1870 o espírito alemão. " Como crítico literário, advogado, estudioso da religião, político e filósofo, Tobias Barreto personificou a Alemanha triunfal através do trabalho de recepção, no Brasil, de sua cultura presente em seus autores, poetas, filósofos, entre os quais destaca-se Nietzsche.

Ora, a Escola Superior de Teologia, em suas diferentes fases, também compreendeu em Nietzsche uma personalidade marcante não apenas no campo filosófico, mas também no campo literário, poético. Atestamos esta afirmação a partir de uma referência a data de seu aniversário de morte no calendário de datas comemorativas para a comunidade evangélica luterana. No calendário da Revista luterana (Deutsche Evangelische Blätter für Brasilien), Páginas Evangélicas Alemãs para o Brasil relativa ao ano 1950, mês de Agosto no dia 25 (Domingo) uma menção a data de falecimento de Fr Nietzsche + 1900, o mesmo é considerado um Philosoph und Dichter (filósofo e poeta). ${ }^{2}$

1 Dohms, 1931, p. 63

2 Deutsche Evangelische Blätter für Brasilien, 1950

Cad. Nietzsche, Guarulhos/Porto Seguro, v.40, n.3, p. 241-267, setembro/dezembro, 2019. | 245 
Feiler, A. F.

Chama a atenção seu nome figurar entre as datas comemorativas do calendário luterano. Apesar da iconoclastia do filósofo, este possui um espaço de reconhecimento entre uma das instituições que é um dos alvos principais de ataque do filósofo. Seu reconhecimento pela Igreja Luterana se dá pelo pensamento, centrado principalmente em seu ataque a burguesia e uma melhor compreensão da essência do Cristianismo, e pelo aspecto poético, sua arte magistral na escrita, que, tal como o próprio Lutero, é considerado um dos fundadores da língua alemã. Nietzsche compreende a arte de escrever como uma das formas de se educar a memória daqueles que o leem. Por essa mesma razão, ele revela no Zaratustra que escreve com sangue. A escrita com sangue marca na memória daquele que o lê a mensagem que se ser apresentar. Quando se fala em mensagem a ser guardada, Nietzsche, mais uma vez, se mostra tributário da tradição cristão luterana. Pela centralidade da doutrina luterana na Sagrada Escritura se revela a necessidade de se exercitar uma técnica: a técnica da memória. Dependendo da forma com que se diz algo se pode ou não ser memorizado. Por isso, que Lutero se esmerou tanto no trato de tradução alemã da Bíblia. Tal expediente formal também foi observado por Nietzsche em seus escritos. Por mais que ele se coloque contra as técnicas da memória, ele pode ser considerado um dos grandes marcos na difusão das ditas técnicas.

O estilo marca profundamente, imprime um selo singular, irrepetível, e, por ele, se constrói a base do filosofar, base esta profundamente reconhecida pela então nascente Escola Superior de Teologia. A recepção do pensamento daquele que é considerado o maior crítico e opositor do luteranismo, tem em seu estilo um expediente fecundo: aquele do enfeitiçamento e da magia. A beleza e a magia, que se depreendem da estilística, conduz os que dela se aproximam. Tal a tática, como vimos, utilizada pelo Pai da Reforma ao pôr em suas mãos a letra daquela que passa a ser a única fonte material da salvação: a Escritura. A fim de propor o seu projeto 
A recepção de Nietzsche na Primeira Escola de Formação Pastoral...

de renovação cultural pela desconstrução, Nietzsche realiza um procedimento parecido ao se utilizar do expediente do estilo. Pelo estilo, o filósofo põe em marcha o seu projeto de transvaloração de todos os valores.

Não pelo transvalorar todos os valores ocidentais que a Escola Superior de Teologia reconhece em Nietzsche a sua grandeza, mas pela arte estilística. Ou seja, não pelo conteúdo de seus escritos, mas pela sua forma. A elegância e o estilo oferecem aos teólogos um expediente salutar em seu ministério, o de levar o rebanho a aderir pela fé. Quanto mais bem elaborada do ponto de vista formal for uma instrução ou prédica, tanto mais reconhecimento e respaldo terá junto aos fiéis. Pelo estilo de escrever seus textos, Nietzsche goza junto à Escola Superior de Teologia reconhecimento e respaldo. Ora, isso não quer dizer que tal expediente, em Nietzsche, faz dele o maior filósofo, pronto a desbancar Kant. Não, mas o conecta a uma tradição que caminha em busca de referenciais culturais baseados no estilo e no bom gosto, ingredientes estes que fizeram de Nietzsche um grande marco referencial. Ele é referido como o filósofo, pelo seu pensamento atávico e provocativo, principalmente com relação ao Cristianismo, mas também é referido como o poeta, pois a poesia, sob a qual escreve a maior parte de seus textos, dá a eles um tom imaginário, belo e provocativo. Eis pois a sua tática estilística: fazer do leitor alguém provocado a ir além de si mesmo, investindo naquilo que lhe é peculiar, irrepetível, singular. É pensando a partir destes indicativos de peculiaridade e singularidade que se avançará em termos de liderança mnemônica. Tanto mais facilmente a memória irá ser retida e a mensagem gravada.

Em termos estilísticos, a recepção do pensamento de Nietzsche evoca, inclusive, aquela personagem lendária que intitula uma das obras mais famosas do filósofo, Assim falava Zaratustra. Nessa obra, Nietzsche atinge o nível mais alto de seu estilo aforismático, o que atesta, mais uma vez, a sua identidade poética. Em uma 
Feiler, A. F.

passagem da revista Deutsche Evangelische Blätter für Brasilien, Ferdinand Schröeder escreve: "O homem é mais predisposto ao mundo sensível ao físico, ele está mesmo em perigo de perder seu senso do supersensível. Mas esse perigo é encontrado por Zaratustra." $\mathrm{O}$ Pastor Schröeder, mediante essa referência a Zaratustra, em seu artigo intitulado Teosofia e Cristianismo atualiza as críticas de Nietzsche ao positivismo cientificista. O positivismo é um dos alvos da crítica de Nietzsche, por tecnicisar todas as dimensões da vida humana, como é o caso da educação. Por essa razão, o acento que Nietzsche dá à esfera da arte, da estética, expressa pela estilística, consiste numa das formas pelas quais o filósofo reage às invectivas tecnicistas. Se o seu humano se apegar em demasia ao físico, incorre em perigo de perder sua sensibilidade ao que vai além do físico. Ou seja, na medida em que as referências humanas estiverem centradas na esfera puramente científica, tanto mais dificuldades terá em direcionar sua sensibilidade à esfera supra-sensível. $\mathrm{O}$ personagem de Nietzsche, Zaratustra se depara com este impasse ao descer da montanha, onde permaneceu por longo tempo cultivando o seu espírito. O seu deparar-se com a balbúrdia da praça revela a dificuldade do silêncio para o cultivo de si. Tal cultivo aponta para a meta, que é a da superação de si, pelo caminho do animal ao além-do-homem, tal como lemos "O homem é uma corda, atada entre o animal e o super-homem - uma corda sobre um abismo." (NIETZSCHE, ZA/Za, Prólogo, 4, KSA 4.16). Ao transitar do estado de homem, atado ao mundo físico, sensível, para o estado supersensível, o homem se supera a si mesmo, deixando a simples condição de homem para a condição de além-do-homem. Zaratustra, ao se dar conta dessa necessidade trata de ele mesmo fazer o processo. Contudo, ao querer se dispor aos outros a fazerem o mesmo, quase sucumbe, razão pela qual diz “[...] não sou a boca para esses ouvidos." (NIETZSCHE, ZA/Za, Prólogo, 5, p. KSA 4.18).

3 Schröeder, 1924, p. 141

248 | Cad. Nietzsche, Guarulhos/Porto Seguro, v.40, n.3, p. 241-267, setembro/dezembro, 2019. 
A recepção de Nietzsche na Primeira Escola de Formação Pastoral...

O dar-se conta de não ser a boca para certos ouvidos corresponde a evitar o perigo de sucumbir à esfera do âmbito puramente físico.

É bastante curioso que a recepção de Nietzsche na Escola Superior de Teologia vai se dando mediante a importância do exercício do cultivo de si pela estilística, para além de todas as invectivas iconoclastas do filósofo. No entanto, o cultivo de si é um elemento fundamental da própria teologia luterana. $\mathrm{O}$ ser humano, na perspectiva de Lutero, enceta o seu caminho na condição de pecador para a de nova criatura regenerada pela graça santificante de Cristo unicamente pela sua fé. O pastor Schröeder evoca a Zaratustra em seu artigo para mostrar, através de sua atitude de ultrapassamento da condição de homem para a condição de além-do-homem, a necessidade que cada ser humano tem em seu caminho na vida cristã. O além-do-homem de Zaratustra é lido por Schröeder como o novo homem regenerado pela graça cristã. Este caminho de regeneração é dado pela superação da esfera física, mediante a inclinação à forma. Ou seja, mediante o devotamento à arte que se expressa na estilística. Este caminho para o além-do-homem, para a sua superação é um caminho singular; é um caminho de afirmação de si mesmo, que passa pelo auto cultivo. Em que medida este aspecto auto afirmativo de Nietzsche perpassa a recepção de seu pensamento junto a Escola Superior de Teologia?

\section{Nietzsche e o seu Selber Aner (ele mesmo)}

Toda a filosofia de Nietzsche consiste num esforço de afirmação de si mesmo. E este esforço liga-se à máxima nietzschiana de fidelidade à terra, tal como tem sido protagonizado por Zaratustra. Nietzsche, ao falar de fidelidade, toca em um dos pilares centrais da teologia luterana: a fé; não a fé na transcendência, mas uma fé imanente, devotada às coisas deste mundo. $\mathrm{O}$ filósofo alemão utiliza do mesmo recurso utilizado pelos crentes protestantes, contudo os inverte. Desse modo, faz com que as preocupações de Paulo de Tarso sejam desmentidas; não mais as coisas do alto e sim as coisas de 
Feiler, A. F.

baixo. Pois é na elevação destas coisas que o filósofo alemão via a transfiguração do humano.

Sob o aspecto da afirmação de si mesmo, Nietzsche é recepcionado pela Escola Superior de Teologia como o mestre do si mesmo, daquele que está para além do rebanho. O próprio Lutero via no esforço individual o caminho para a salvação. Somente ele, o homem individual, com a força de sua fé, para além do rebanho, da Igreja seria capaz de encetar o caminho rumo a sua redenção. Na própria doutrina luterana a salvação se dá por obra de Deus no coração de cada crente em particular. Um pequeno texto publicado na Revista Deutsche Evangelische Blätter für Brasilien, no dia 02 de maio de 1920, ilustra este aspecto da individualidade que ora exploramos

Dom Franz Lachner (maestro nascido em München em 1890) conta com uma palavra bonita. Pergunta sobre uma música profunda, a qual a direção musical ele presta homenagem, seja da wagneriana, da schumariana, da mendelsoniana ou também da litzianiana, respondeu o honesto suábia, e neste caso seu olho relampeja: "wagneriana? schumariana? Nada disso.... ele mesmo" Ele sente-se como personalidade musical e ele mesmo mais que uma criação tem provado a autonomia de seu talento musical.

O que deve ser designado com a palavra "personalidade, é o singular (particular) de um caráter espiritual, a autonomia da vontade e a convicção, o estar auto introspectivo, ser indeterminado ao redor da moda respectiva e concepção temporal. Semelhantes personalidades têm os alemães jamais podido alegrar-se, e tem o povo vivido grandes tempos, assim conduziramlhe para grandes personalidades em tais tempos. Nós podemos contar dos períodos de tempo, e dizer onde uma grande série de personalidades com um círculo de estrelas brilhou no céu alemão, e nós pensamos com suspiros no tempo, onde sem nenhuma estrela o céu permaneceu escuro. Porém as lâmpadas deste estava então verdadeiramente refrescante....

O contraste da personalidade é o padrão. Queremos dizer: quando a "personalidade" está ausente faz-se amplo o padrão. Homens com costas de borracha... sem força própria e convicção robusta... Lakaten, que sorridente encurva-se, como e onde pedirá... Alma obediente com o movimento do antebraço automático: dá teu óbulo e dá ordens sobre meus orgulhos. Dos 
mais velhos se conhece estes padrões humanos, que caminham sem marco e força dos caminhos calcados... eles encontram-nos sobre passo e passada (vestígio), eles têm sempre um sorriso obrigatório, eles jamais falam uma palavra ofensiva, eles são mestres na forma, porém de espírito desolador. Friedrich Nietzsche pois chamou-os bem de homens de rebanho porque eles seguem às cegas seus pastores, chamam então juízo temporal ou chefe do partido, ou jornal ou slogan de eleição. Sua característica é sua falta de independência espiritual.

Ele mesmo. Depois vem. Nosso tempo é a preparação e o meio de formação das personalidades robustas não oportunas. Sim, isso é real como um prodígio para contemplar, quando hoje em dia uma vez um comparece com uma convicção vigorosa sobre o plano. Partido e padrão estão abalizados para o presente. E justamente o partido que em nome da liberdade e do direito da humanidade pretende para combater, deixa em sua série junto ao guia jurado nascer sua personalidade.

Assim diz Karl Storch com direito. Nós conduzidos à universidade: ele mesmo! Depois vem, também sua pergunta religiosa. Isso se dava no tempo antigo, lá a Igreja exercia uma coação e necessitava coragem para divergir da confusão eclesiástica, nós temos hoje o contrário. Os dias atuais - e desde há muito, trata-se de como inculto, como antiquado, seu próprio pensamento para pensar sobre Deus e o Reino de Deus, sobre consciência, pecado, imortalidade. É moderno, repetir apenas, o que o partido do papa diz e os jornais. Isso não nos deixa mais tolerar. Sem querer... seu ele, senão homens de auto pensamento. Nós queremos acreditar em Deus e nossa fé aberta testemunha, se nós mesmos disso estamos convencidos. Nós queremos educar nossa fé e nisto ensinar a fé de nossos filhos. Onde aos incrédulos será concedida liberdade, deve-se conceder também a liberdade da fé.

Para fora do padrão do partido! Para fora da servidão espiritual da moda! Liberdade apenas para uma direção não é liberdade. Se eu tenho compreendido, que eu tenho direito, assim devo me também não impedir de ser seu mais jovem discípulo. Ele mesmo. ${ }^{4}$

O texto acima evoca a necessidade da personalidade, ou seja, da convicção a fim de que se afaste aquele sentimento de que tudo

4 Deutsche Evangelische Blätter für Brasilien, 1920, p. 29

Cad. Nietzsche, Guarulhos/Porto Seguro, v.40, n.3, p. 241-267, setembro/dezembro, 2019. | 251 
Feiler, A. F.

deve estar submetido a um padrão único. Por essa razão, o nome Friedrich Nietzsche cai como uma luva a ilustrar tal argumento em favor da constituição de uma personalidade capaz de romper modelos fechados rumo a uma independência espiritual, ditada unicamente pela consciência da lei da liberdade, mediante a qual cada um foi escolhido. Por isso, não há partido, e sim o discipulado universal daqueles que compreenderam o que significa liberdade, a liberdade da fé. Estes, distantes da vista de seus pastores, vivem uma personalidade robusta. $\mathrm{O}$ artigo é bastante ousado para a época em que foi escrito ao criticar abertamente a instituição religiosa, em questões como Deus e o Reino de Deus, sobre consciência, pecado, imortalidade. Constitui num clamor diante do fato de não ser mais possível reproduzir o que se encontra pré-determinado, mas desvencilhar-se das amarras que por todos os lados pretendem comprometer a liberdade.

É curioso o fato de que um artigo como este, veiculado a uma revista, que é a principal representante, na época, da Igreja Evangélica de Confissão Luterana no Brasil, teça uma crítica tão aberta ao modelo institucional que ela mesma vive. E para tanto, inclusive, evoca o nome daquele que é considerado o seu crítico mais agressivo, Nietzsche. Há, entre as linhas do fragmento acima, um convite incessante a ser si mesmo. E ser si mesmo implica em romper o padrão, o partido a fim de se revestir de personalidade; a personalidade de ser si mesmo.

A referência que o fragmento faz ao papado, evocando a ideia de uma repetição de tudo o que diz o papa, reproduz o sentimento de uma época entretecida por embates entre as igrejas de confissão Católica e Luterana. Embates estes, em grande parte, fomentados pelo regime imperial, que proclamava a Igreja Católica como Igreja oficial do país. Ora, por mais que Nietzsche tenha se rebelado contra o Cristianismo, e, de modo especial, contra o Cristianismo luterano, o que ele viveu, não se tem como negar a forma pela qual o autor 
do artigo toma o pensamento do filósofo, como uma ferramenta para auxiliar em sua crítica.

Nietzsche é claramente mencionado no artigo como aquele que aponta a ferida: o rebanho, como um dos grandes males pelos quais passa a cultura e a sociedade. Frente a tal diagnóstico se impõe o exercício da crítica, que se constrói como desconstrução da atual ordem estabelecida. É um verdadeiro romper paradigmas que se assentam em padrões fortemente emoldurados para conduzir à construção de uma personalidade própria, individual, que pense com a sua própria cabeça, que siga os seus instintos, que se afirme a si mesma. O filósofo alemão, com isso, passa ser considerado um Apóstolo da quebra de paradigmas, um arauto da constituição da independência espiritual, um pai da liberdade das inclinações. Estas características, de qualquer forma, evocam a ânsia de liberdade desenhada pelo próprio Lutero. Para além de todas as críticas que este endereça ao Cristianismo, em particular, ao Cristianismo Protestante, há em Nietzsche e Lutero um elemento comum: o da afirmação do si mesmo. Assim como Lutero se impôs, com a liberdade de sua consciência, frente aos seus detratores, Nietzsche, por sua parte, se impôs frente a uma mentalidade inclinada sob o peso da moral. $\mathrm{O}$ si mesmo individual se impõe, em ambos autores, frente às imposições promovidas pela moral gregária.

Ainda na esteira deste contexto do rebanho, lemos em uma passagem deste mesmo periódico publicado na Escola Superior de Teologia o seguinte

Friedrich Nietzsche provavelmente os chamava de pastores, na medida em que seguiam cegamente o seu guia, este agora era chamado de justiça temporal ou líder de partido, Jornal ou slogan eleitoral. Sua característica é a independência mental. ${ }^{5}$

5 Deutsche Evangelische Blätter für Brasilien, 1920, p. 29.

Cad. Nietzsche, Guarulhos/Porto Seguro, v.40, n.3, p. 241-267, setembro/dezembro, 2019. | 253 
Feiler, A. F.

Vemos através dessa passagem a associação do nome de Nietzsche aos pastores, e, por consequência, uma referência àqueles que existem graças aos primeiros. O pastor é o guia dos que o seguem de maneira cega e irrestrita. Ora, Nietzsche, por ser o grande crítico desta vivência gregária, acaba por ser apresentado como aquele que ajuda a desvendá-la. Contudo, mais adiante, nesta mesma passagem, temos o anúncio de uma organização, um partido que se estrutura em torno a um líder não afiliado a um sistema formatado sob os auspícios de uma obediência irrestrita, mas que é livre. Ele não depende de um outro, pois confia em si mesmo. Ora, na visão teológica luterana, o fiel não pode se determinar por qualquer líder que seja, mas, examinando sua consciência lhe é concedida a possibilidade de optar, desse modo, evita-se que se sofra de consciência, pois que, em consciência, ninguém pode ser forçado a agir contra as suas convicções.

Nietzsche é recepcionado entre os imigrantes alemães, assim como entre os descendentes daqueles, como o grande guia de si mesmo. Ora, o guia de si mesmo procura investir na prática do cultivo de si, um cultivo, acima de tudo, espiritual, não devotado ao que os outros lhe impõem como regra a seguir, mas como vida a viver daquilo que se manifesta de mais original e genuíno. Como lemos nesta passagem, escrita pelo pastor Theodor Dietschi, em seu artigo Kolonization und Kirsche: “(...) isto para falar sobre os mestres da forma e de espírito desolado, os cultivadores da música wagneriana, schumariana, mendelsoniana e listiniana. ${ }^{6 "}$ A música é uma forma de cultivo de si, de modo que a sua forma nos eleva para além do conteúdo linguístico nela associado. Dela Lutero faz o grande instrumento de seu apostolado junto ao povo, principalmente pela introdução da polifonia e do canto coral em língua vernácula. Os músicos evocados fazem parte do repertório nietzschiano, de maneira especial, Wagner, com quem viveu um misto de amor e ódio. O gênio

6 Dietschi, 1920, p. 30

254 | Cad. Nietzsche, Guarulhos/Porto Seguro, v.40, n.3, p. 241-267, setembro/dezembro, 2019. 
A recepção de Nietzsche na Primeira Escola de Formação Pastoral...

musical de Wagner constituiu, em sua tragicidade, um antídoto contra a dor da resignação gregária; embora tenha posteriormente se traduzido num verdadeiro algoz na vida de Nietzsche.

Em certo sentido, com todas as ressalvas, Nietzsche inspirou o modo de se organizar da vida luterana naquilo que lhe corresponde como liberdade de consciência e/ou independência espiritual. A forma como o filósofo lida com a preservação incólume daquilo que, no ser humano, é mais singular, seu ser si mesmo, levou teólogos luteranos a se aproximar de seu pensamento, munidos de uma pinça, a fim de extraírem aspectos que pudessem auxiliar na atualização do luteranismo em terras sul brasileiras. Mas aquela passagem anterior evoca um guia, um líder de si, escrita no ano de 1931, faz referência evidente ao partido nazista, então em voga naquele período. Em que medida a recepção do pensamento nietzschiano, junto a EST, foi sustentada por sua associação ao nazismo?

\section{O Barteifiihrer (líder do partido) de Nietzsche}

Chegamos a um ponto bastante delicado quanto à recepção de Nietzsche na Escola Superior de Teologia; examinar em que medida as motivações do partido nazista, que entusiasmaram os membros da Igreja de Confissão Luterana na Alemanha e também no Brasil, tiveram como base os escritos de Nietzsche. Este último, como é sabido, foi instrumentalizado pela sua irmã Elisabeth Forster, com o objetivo de expandir a sua venda, num período em que o pensamento do filósofo alemão atraiu tanto a atenção dos nazistas. $\mathrm{O}$ próprio Hitler visitou o arquivo Nietzsche em Weimar, ao que se tem notícias, pelo menos duas vezes.

O movimento nazista teve como motivação, desde a sua fundação, operar uma revolução estética, dentro do macroprojeto de revolução das culturas, capitaneado por Otto Bismark. Neste sentido, a produção nietzschiana com todo o seu aparato estilístico certamente impressionou os membros do partido nazista, a ponto de 
Feiler, A. F.

adotarem o Zaratustra como livro de cabeceira dos soldados nazistas. Certamente foi, entre outros elementos, pela estética que os nazistas viam em Nietzsche um grande mentor intelectual, a embasar os ideais que os moviam em seus empreendimentos.

Nesta citação, a seguir, escrita pelo Pastor Friedrich Wilhelm Brephol, intitulada Goethe und Christenthum (Goethe e o Cristianismo) na página 28 da Deutsche Evangelische Blätter für Brasilien 13. Jahrgang August 1931 Heft 8, percebemos que apesar de oposto ao Cristianismo, Nietzsche gozava de prestígio entre os círculos luteranos, justamente pela sua inclinação estética. Muito embora era visto como um pensamento que inspirava uma certa formalidade vazia, exercia um fascínio sobre os seus leitores:

O ensino dos confimandos, que ele saboreava, e meramente no ensino de cor, fragmentos do cabeçalho do catecismo - como naquele tempo era habitual - revestido, podia dar-lhe nada, sentia falta daquele professor, que como junto a Wilhelm v. Krügelgen (Recordação de um grande homem) que o Cristianismo de Schüler para evocar a intimidade viva. Assim isso vinha, que na oposição de outra grande mente como - por exemplo Friedrich Nietzsche - a confirmação dava-lhe nada, senão era uma formalidade vazia. Que junto a um jovem, que na profunda veneração de Deus do impulso interno, como ele mesmo nos escreve, um dia construiu um altar a seu Deus e queria oferecer vítimas. Estavam ausentes mesmo os homens da Igreja de seu tempo, os quais foram estimulados pelo amor a juventude para a fonte da água do Evangelho. Apenas a proclamação da Palavra protestante de seu tempo, distingue-se da afiada proclamação evangélica do tempo da Reforma, que repeliu um Angelus silésio no mosteiro, Goethe não podia pedir ao piedoso temente a Deus. ${ }^{7}$

Nietzsche é evocado como uma grande mente, como um pensador de capacidades, e mesmo a evocação da oposição às suas ideias não representa diminuição de sua grandeza intelectual. O simples fato de ser lembrado já por si só representa sinal de reconhecimento e

7 Brephol, 1931, p. 28

256 | Cad. Nietzsche, Guarulhos/Porto Seguro, v.40, n.3, p. 241-267, setembro/dezembro, 2019. 
A recepção de Nietzsche na Primeira Escola de Formação Pastoral...

grandeza. Com relação ao nazismo não foi diferente. $\mathrm{O}$ fato de ser lembrado, tal como o foi no âmbito religioso, não quer dizer que seu pensamento tenha sido, pelo menos diretamente, inspirador dos ideais nazistas. Se não inspirador, pelo menos simpático a tais ideais, pelo menos em alguns aspectos. E quais poderiam ser estes aspetos, em que o pensamento de Nietzsche representou uma fonte de inspiração para os ideais nazistas, tal como compreenderam os que recepcionaram o seu pensamento junto a Escola Superior de Teologia em São Leopoldo?

Em primeiro lugar há uma leitura nacionalista sobre Nietzsche, o que testificam diferentes passagens, onde lemos, por exemplo: "Se distingue corretamente entre folclore e nacionalidade ou, como se diz, 'nacionalismo político' e designa isto o folclore, uma natureza boa, que é para atender ao dever. O espiritual que uma Igreja internacional serve, é por isso desempenhado por sua obrigação, para atender e promover para si e para seu povo estes bens naturais. ${ }^{8 "} \mathrm{O}$ nacionalismo político é considerado como um bem natural a ser assegurado ao povo, como algo que, sem o qual, um povo não tem como existir enquanto povo. Esse sentimento de povo se estende tanto para os alemães que vivem na Alemanha como para os alemães que estão no Brasil, bem como de seus descendentes. "Ainda permanece também nossa comunidade nacional em uma crise no meio disso. Sempre mais ela entra na essência da vida brasileira, porém ainda falta o seu líder, ainda falta vós como coletividade, que será constituído e formado, sob a localização determinada para permanecer firme. Ainda nós celebramos por causa disso o dia da imigração alemã. ${ }^{9}$ " Se sente o quanto a comunidade germânica brasileira olha para a sua antiga pátria com orgulho, e o desejo de permanecer unida a ela em seus ideais de nação. Contudo, almeja-se o líder, aquele que promoverá a

8 Deutsche Evangelische Blätter für Brasilien, 1931, p. 20

9 Deutsche Evangelische Blätter für Brasilien, 1931, p. 92

Cad. Nietzsche, Guarulhos/Porto Seguro, v.40, n.3, p. 241-267, setembro/dezembro, 2019. | 257 
Feiler, A. F.

ordem e a firmeza, bem como o cultivo de valores que são a garantia da sua unidade.

Esta publicação que segue apresenta de forma bastante clara as diversas relações que membros do presbitério da Igreja Luterana mantinham com oficiais nazistas.

A defesa da Igreja Evangélica Alemã confirmou as decisões do presidente Kapler e o presidente deu pleno poder para negociações. Sob o lado do Nacional Socialismo é para averiguar em terceiro lugar, que Adolf Hitler encarregou muitas vezes o prussiano o pastor multi circular Müller, como intermediário entre o Estado e os oficiais da Igreja Evangélica do lugar para trabalharem. Finalmente não é sem importância que a nomeação dos comissários de Estado para a Igreja vem em nenhuma forma mais prática em pergunta. ${ }^{10}$

Como lemos, o próprio líder nazista estabeleceu negociações com pastores da Igreja Luterana para trabalhos comuns. Daqui é possível verificar que uma das razões que tanto o partido nacional socialista como a Igreja Luterana mantinham relações de estreitamento era o fato de que ambas as partes valorizassem os valores da nação, da pátria. Os nazistas, pelo seu lado, com os valores de fazer da Alemanha uma grande nação, bem acima de todas as outras, e a Igreja Luterana, por sua parte, com o cultivo de um ideal de Igreja independente dos desmandos papistas, o que lhe possibilita o cultivo de sua cultura, sua língua, seus costumes.

Um outro artigo apresenta o título seguinte: "Com Adolf Hitler na Guerra" Uma das frases do artigo diz: “Adolf Hitler, o homem da vontade séria, consciencioso, poderia ser ingente jovial." $\mathrm{O}$ artigo mostra abaixo uma foto da época em que o líder nazista se encontra em visita a uma enfermaria que atende crianças em Wittenberg. Hitler observa atentamente, com jovialidade, uma criança deitada em seu berço. Chama a atenção que, embora se reconheça a dura cerviz do

10 Deutsche Evangelische Blätter für Brasilien, 1933, p. 18

258 | Cad. Nietzsche, Guarulhos/Porto Seguro, v.40, n.3, p. 241-267, setembro/dezembro, 2019. 
ditador, ao mesmo tempo se é capaz de o qualificar de jovial. Um monstro, mais um monstro jovial. Outro elemento importante é que essa visita acontece em Wittenberg, local onde aconteceu a Reforma Protestante, portanto bastante emblemático para a Igreja Luterana. Em seguida, logo na página seguinte se lê em letras garrafais

O povo diante de Deus! O líder Adolf Hitler fala: Nós queremos ser ativos, trabalhar, suportar-nos fraternalmente, lutar juntos, que um dia aproximase a hora, lá nós diante do Senhor podemos apresentar-nos e lhe pedir: Senhor, tu vês, nós temos nos emendado. $O$ povo alemão não é mais o povo da desonra, da vergonha, da auto dilaceração, da pusilanimidade, da pequena fé. Não, Senhor, o povo alemão está forte novamente em sua vontade, forte em sua perseverança, forte em suportar todo o sacrifício. Senhor, nós não deixamos diante de ti. Agora abençoe nossa luta para a nossa liberdade, e com isso nosso povo alemão e nossa pátria. ${ }^{11}$

Podemos notar o quanto as palavras persuasivas de Hitler têm conquistado o povo alemão, e, inclusive, membros do presbitério da Igreja Luterana. Sua arte persuasiva se depreende, particularmente, da carga de ânimo que ele injeta na confiança da capacidade do povo alemão em superar todos os tipos de obstáculos. Particularmente, chama a atenção expressões utilizadas por Hitler como ser ativo, força na vontade, suportar sacrifícios. Estas expressões recordam temas que se depreendem do pensamento nietzschiano, a necessidade de se colocar numa postura ativa, afirmativa diante do niilismo, a vontade de potência, de auto superação, a força que se depreende para enfrentar sacrifícios, os mais pesados e difíceis, numa dinâmica que só se torna possível mediante os auspícios do amor fati, a acolhida jubilosa e afirmativa do destino.

Vemos pelas palavras que se depreendem do discurso de Hitler aproximações significativas com o pensamento de Nietzsche, o que, mais uma vez, nos leva a constatar uma das razões pelas quais a

11 Kalender Deutsche Evangelische Gemeinden in Brasilien, 1937, p. 121

Cad. Nietzsche, Guarulhos/Porto Seguro, v.40, n.3, p. 241-267, setembro/dezembro, 2019. 259 
Feiler, A. F.

Igreja Luterana, tanto na Alemanha como no Brasil, tem encontrado no pensamento do filósofo elementos que respondem aos seus anseios pessoais e coletivos. Apesar do ateísmo do filósofo, a aparente crença de Hitler tem um tom instrumentalizador. O Senhor Deus, que Hitler evoca diz respeito àquele Deus que vem ao encontro da vontade do ser humano, daquele Deus que, em tudo, se conforma aos desejos de auto superação do ser humano. Logo, o foco do discurso de Hitler é puramente antropológico, com um véu religioso sobreposto apenas para causar impressão. O próprio título de Führer (líder) é evocado para apontar uma qualidade de auto superação. "O Líder. O homem que adquiriu este nome através da guerra dura: Adolf Hitler. Que é seu título, o líder." (1937, p.119) O líder se constitui na medida em que é capaz de enfrentar as mais duras penas da existência, só assim pode se auto superar.

Ele liderou primeiro a poucos, outra vez não eram 10 homens, quando ele começou sua luta para a salvação da Alemanha. Sempre mais impelia para ele naturezas fortes, para serem batizadas. Ano a ano passaram a ser milhões. Então, finalmente, 1933, foi criado, Adolf Hitler foi o líder responsável de todo o povo alemão. Sem chefe de um Estado sob todo o globo terrestre pode um tal sequaz mostrar como Adolf Hitler, detrás de todo o povo alemão não está de modo nenhum presenciado. ${ }^{12}$

É interessante a constatação deste líder que vai se fazendo pela sua aproximação a naturezas fortes até a sua hegemonia como líder de todo o povo alemão.

Hitler disse em 1933 em um discurso: sobre a minha lápide não deve-se escrever nada senão: Aqui descansa em paz Adolf Hitler. Pois este nome não necessita nenhum título, o nome Adolf Hitler é mais que todo o título do mundo. Porém, sua fidelidade, que o povo alemão encontrou para o nome que exprime o que Adolf Hitler é: Führer (líder). ${ }^{13}$

12 Kalender Deutsche Evangelische Gemeinden in Brasilien, 1937, p. 119

13 Kalender Deutsche Evangelische Gemeinden in Brasilien, 1937, p. 119

260 | Cad. Nietzsche, Guarulhos/Porto Seguro, v.40, n.3, p. 241-267, setembro/dezembro, 2019. 
A recepção de Nietzsche na Primeira Escola de Formação Pastoral...

Esta designação tem elementos muito próximos àqueles do além-do-homem de Nietzsche. "Eu vos ensino o super-homem. O homem é algo que deve ser superado." (NIETZSCHE, KSA, Za, Prólogo, 03, IV, 1999. p.14). O tema do super-homem traz aspectos da auto superação, aquele que está além de si mesmo. "Ao homem se aferra minha vontade, com cadeias me amarro ao homem, porque sou impelido para cima, rumo ao super-homem: pois para lá quer ir minha outra vontade." (NIETZSCHE, KSA, Za, II, Da prudência humana, IV, 1999, p.183). O super-homem é igualmente evocado mediante o tema da vontade. Pela vontade com a qual o ser humano se coloca na posição de poder. "Foi também lá que recolhi do caminho a palavra 'super-homem', e que o homem é algo que tem de ser superado - o homem é uma ponte e não um fim." (NIETZSCHE, KSA, Za, III, De velhas e novas tábuas, 03, IV, 1999, p. 248). O homem que se supera é um meio que tende a chegar a algum lugar, portanto é frágil, razão pela qual terá uma dura jornada pela frente: amor fati. Os temas da auto-superação, da vontade de potência, e do amor fati, se depreendem da figura do super-homem e, da mesma forma trazem presente aquele discurso de Hiller acima transcrito. Responder à pergunta se o pensamento de Hitler foi usado corretamente ou deturpado pelos nazistas, não nos propomos fazê-lo aqui, pelo menos neste momento, mas apenas mostrar que na recepção de Nietzsche na EST a ligação do pensamento de Nietzsche ao nazismo é bastante estreita. O pensamento do filósofo foi utilizado para justificar a adesão da Igreja Luterana ao nazismo, precisamente por uma leitura nacionalista que dele se fez. Isto se revela uma utilização indevida, pois o pensamento de Nietzsche não defende nenhum tipo de partido nacionalista, ao contrário, combate, designando-os de moral gregária. 
Feiler, A. F.

\section{Considerações finais}

A recepção do pensamento de Nietzsche junto a primeira escola de formação de pastores da Igreja Luterana no Brasil, revela uma realidade dúbia: por um lado temos uma leitura que revela uma originalidade estilística do autor, bem como a originalidade de sua autoafirmação, por outro, temos uma leitura instrumentalizadora de seu pensamento, ao associá-lo ao nazismo. Desse modo, é possível perceber, em linhas gerais, que a recepção do pensamento de Nietzsche se deu, em grande medida, mediante a busca de respostas a questões diversas ao seu pensamento. Em outras palavras, seu pensamento foi, num grau elevado, forçado. Como sua escrita é carregada de palavras e expressões com energia, força, acabam por entusiasmar a tal ponto o seu leitor a ponto de que sua leitura seja perpassada por usos abusivos. $\mathrm{O}$ que resulta em comprometer a sua interpretação. Com isso, fica difícil saber até que ponto se está lidando com o texto de Nietzsche, já que a forma com que a seu pensamento se lida, em muitos casos, conduz a um maior obscurantismo do mesmo.

A investigação que ora fizemos ajuda a trazer esclarecimentos sobre o ambiente no qual o pensamento de Nietzsche foi recebido. Com isso, se tem clareza sobre as intenções subjacentes que levaram a buscar em seu pensamento respostas para determinadas questões. A criação da Escola Superior de Teologia no Brasil responde a um anseio de ter em solo brasileiro a própria escola. Com isso se pode melhor controlar o tipo melhor de formação a que se pretende. Uma formação que, em comunhão com a formação alemã, traz para as terras brasileiras aquele sentimento nacionalista. Um sentimento que se expressa no uso da própria língua alemã, seja para fins de estudo, culto, encontros formais e informais. Ora, a língua constitui um fator de identidade nacional. Por essa razão, com o uso da língua, os alemães aqui residentes, bem como seus descendentes, se viam num laço de união com os seus compatriotas na Alemanha. E a língua, na concepção de Nietzsche é umas das expressões da arte.

262 | Cad. Nietzsche, Guarulhos/Porto Seguro, v.40, n.3, p. 241-267, setembro/dezembro, 2019. 
A recepção de Nietzsche na Primeira Escola de Formação Pastoral...

A beleza de sua forma evoca a riqueza do conteúdo que se expressa em seu enunciado.

Mas além da língua, como expressão da arte, da estilística, temos na recepção de Nietzsche um apelo à afirmação de si mesmo. Uma busca de se diferenciar da massa informe do rebanho. Mais uma vez, aquele sentimento nacionalista move o indivíduo a buscar resguardar aquilo que é o mais próprio e genuíno de si mesmo. $\mathrm{O}$ afirmar a si não pode ser confundido com individualismo, mas com valorizar aquilo que são as expressões singulares, para além da massa gregária. Este sentimento constituía numa verdadeira injeção de ânimo àqueles que, distantes de sua pátria, usos e costumes têm a necessidade de iniciar tudo do zero. Uma outra razão que levava a necessidade de uma injeção de ânimo é o fato de que o Brasil, deste período, é um Brasil Império, por essa razão apenas a Igreja de confissão católica podia se manifestar livremente enquanto religião. As outras denominações cristãs, entre as quais a de confissão luterana, eram recriminadas. Por isso, havia uma necessidade de se afirmar enquanto cristão luterano, afirmando-se a si mesmo diante da massa do rebanho católico.

Entre os destaques da recepção de Nietzsche na EST, à saber, a dimensão da estilística, da afirmação de si mesmo e o envolvimento no nazismo, este terceiro destaque é verdadeiramente digno de nota, pois consiste numa perversão do pensamento de Nietzsche. Com isso se vê que na recepção, tradução e interpretação de um pensamento, seja este qual for, está sujeito a adulterações. E, no caso de Nietzsche isso aconteceu, distanciando-se ainda mais da sua correta interpretação. Não só na recepção de Nietzsche na Escola Superior de Teologia o pensamento de Nietzsche foi associado ao Nazismo, mas quase que de modo geral, sua tradução seguiu os moldes que lhe foram impressos pela sua irmã Elisabeth Forster. O papel dela foi decisivo na maneira como Nietzsche passou a ser lido e interpretado, pois ela mesma, com seu entusiasmo nacional 
Feiler, A. F.

socialista, imprimiu entre os escritos de Nietzsche pensamentos seus que o obrigam vincular ao Nazismo. Isso mostra a grande injustiça a qual foi submetido o pensamento de Nietzsche. Para que esta desmistificação pudesse acontecer foi necessária a consecução de uma edição crítica, a primeira em Nietzsche, organizada por Karl Schlechta. Dali em diante, gradualmente, o seu pensamento foi lentamente se afastando da interpretação nazista. No entanto, como a Edição Crítica de Schlechta somente se deu na década de 50, pelo menos em três décadas anteriores o pensamento de Nietzsche foi lido e interpretado na EST com viés nazista. O que, infelizmente, foi lamentável para a sua correta compreensão.

Diante dos três aspectos que se depreendem, de maneira particular, da leitura e interpretação do pensamento de Nietzsche, ocupa papel de destaque a dimensão do nacionalismo, que foi forjada indevidamente a partir dos seus escritos. O nacionalismo serviu de base para pensar, tanto uma estilística própria, uma forma toda particular de se expressar, como uma afirmação de si mesmo em meio a massa gregário e, principalmente, a adesão ao partido nazista. Contudo, o nacionalismo é, mais uma vez, uma leitura equivocada dos escritos de Nietzsche. Pois, o nacionalismo está vinculado diretamente àquela ideia de rebanho, que tanto Nietzsche combateu. Assim, se Nietzsche defende o nacionalismo, então ele se coloca em contradição consigo mesmo. Não é possível defender o nacionalismo e, ao mesmo tempo, rejeitar o rebanho. Logo, a recepção de Nietzsche junto a EST, não fossem os aspectos ideológicos que o vincularam ao nazismo, teria sido um excelente campo para a leitura e esclarecimento de seu pensamento. 


\title{
The Reception of Nietzsche at the First School of Pastoral Formation of Evangelical Church of the Lutheran Confession in Brazil
}

\begin{abstract}
As descendant of a Lutheran and tradition family, Nietzsche could not be absent of the rich material produced in almost one hundred year of presence of the High School of Theology (EST). Even though the bibliography of that school is eminently turned to theology course, there are several books of philosophy. Between this books that fulfil many philosophy's stands, occur texts written by Nietzsche, as well books written about this author. The majority of this books were written on german language, many of those written on german, but in Brazil. In this article we intend analyze this last writing so as to realize a lecture of as was the Nietzsche's reception in the first school of pastor formation in Brazil.
\end{abstract} Keywords: Nietzsche, Luther, Protestantism, Reception, Brazil.

\section{Referências}

BEUTEL, A. Das Lutherbild Friedrich Nietzsches. Lutherjahrbuch, Goettingen, v. 72 , p. 119-146, 2005.

Deutsche Evangelische Blätter für Brasilien 6. Jahrgang, Heft 4/5, April-Mai, 1924

Deutsche Evangelische Blätter für Brasilien 13. Jahrgang, Heft 8, August 1931

FISCHER, P. Nietzsche, Zarathustra und Jesus Christus. 2. Auflage ed. Stuttgart: Verlag der Evang. Gesellschaft, 1914. 88 p.

GRUETZMACHER, R. H. Nietzsche: ein akademisches Publikum. Leipzig: A. Deichert'sche Verlagsbuchhandlung, 1910. 197 p.

Kalender (Jahrweiser) Deustechen Evangelischen Gemeinden in Brasilien. Heraugegeben in Austrage der Rio Grande Sul Snode, Druck und Bersand Typografia Mercantil/Porto Alegre, Rua Dr Flores Nr. 76, 1937.

Kalender (Jahrweiser) Deustechen Evangelischen Gemeinden in Brasilien. Heraugegeben in Austrage der Rio Grande Sul Snode, Druck und Bersand Typografia Mercantil/Porto Alegre, Rua Dr Flores Nr. 76, 1938.

Cad. Nietzsche, Guarulhos/Porto Seguro, v.40, n.3, p. 241-267, setembro/dezembro, 2019. $\mid 265$ 
Feiler, A. F.

KOHLMEYER, O. Nietzsche und das Erziehungsproblem: Versuche einer einfachen sistematischen Fassung der wichtigsten Gedanken Friedrich Nietzsches ueber Erziehung. Frankfurt am Main: Moritz Diester Weg Verlag, 1925. 162 p.

LOEWITH, K. Gott, Mensch und Welt: in der Metaphysik von Descartes bis zu Nietzsche. Goettingen: Vandenhoeck \& Ruprecht, 1967. 252 p.

LUKÁCS, G. Von Nietzsche zu Hitler: oder Der Irrationalismus und die deutsche Politik. Frankfurt am Main: Fischer Buecherei, 1966. 268 p.

NIETZSCHE, F. W. Autobiographische Schriften und Aufzeichnungen. München: Musarion Verlag, 1928. 372 p. (Gesammelte Werke 21.Band).

. Friedrich Nietzsches Briefe: an Binder, Krug, Deussen, Frhrn. v. Gersdorff, Carl Fuchs, Frau Baumgartner, Frau Louise D., Frhrn. v. Gendlitz u. A.. 3. Herausgegeben von Elisabeth Förster-Nietzsche and Peter Gast. Dritte Auflage. Berlin: Schuster \& Loessler, 1902. 602 p. (Gesammelte Briefe 1.Bd.)

. Friedrich Nietzsche’s Briefwechsel mit Franz Overbeck. Leipzig: Im InselVerlag, 1916. 475 p.

. Friedrich Nietzsche: Werke in drei Baenden. 2. Auflage ed. Darmstadt: Wissenschaftliche Buchgesellschaft, 1958-1960. 3 v.

. Die Geburt der Tragoedie: Schriften aus den Jahren 1869-1873. Leipzig: Alfred Kroener Verlag, [18--]. 515 p. (Nietsche Werke 1. Band)

. Gedichte. Leipzig: Im Insel-Verlag, [19--]. 76 p.

. Jenseits von Gut und Boese: Zur Genealogie der Moral. Leipzig: Druck und Verlag von C. G. Naumann, 1896. 499 p.

. Menschliches-Allzumenschliches I: Vermischte Meinungen und Sprueche; Menschliches Allzumenschliches II, Erste Abteilungen. Leipzig: Alfred Kroener Verlag, [18--]. 604 p. (Nietzsches Werke; 3.Band, 1.Abteilung)

. Morgenröte: Gedanken über die moralischen Vorurteile. Leipzig: Alfred Kroener Verlag, 1930. 338 p. (Kröners Taschenausgabe ; Bd. 73).

. Der Wille zur Macht: Eine Auslegung allen Geschehens. Leipzig: Alfred Kroener Verlag, [19--?]. 376 p. (Nietzsches Werke; Ergaenzungsband) 
A recepção de Nietzsche na Primeira Escola de Formação Pastoral...

. Der Wille zur Macht: Versuch einer Umwertung aller Werte. Leipzig: Alfred Kroener Verlag, 1930. 716 p. (Kröners Taschenausgabe; Band 78)

. Zur Genealogie der Moral. München: Wilhelm Goldmann Verlag, [19--]. $141 \mathrm{p.}$

. Also sprach Zaratustra. In: Kristische Studienausgabe. Heraugegeben von Giorgio Colli und Mazzino Montinari. Berlin: Verlag de Gruyter, 1999.

Recebido em 16/05/2019

Aceito em 25/10/2019

Cad. Nietzsche, Guarulhos/Porto Seguro, v.40, n.3, p. 241-267, setembro/dezembro, 2019. | 267 